\title{
Brown on Brown
}


THIS PAGE INTENTIONALLY LEFT BLANK 


\section{Brown on Brown}

Chicano/a Representations of Gender, Sexuality, and Ethnicity

FREDERICK LUIS ALDAMA

University of Texas Press $\mathbf{v}$ Austin 
Copyright (C) 2005 by the University of Texas Press

All rights reserved

Printed in the United States of America

First edition, 2005

Requests for permission to reproduce material from this work should be sent to Permissions, University of Texas Press, P.O. Box 7819, Austin, TX 78713-7819.

(2) The paper used in this book meets the minimum requirements of ANSI/NISO Z39.48-1992 (Rig97) (Permanence of Paper).

Library of Congress Cataloging-in-Publication Data

Aldama, Frederick Luis, $1969-$

Brown on brown : Chicano/a representations of gender, sexuality, and ethnicity / Frederick Luis Aldama. - ist ed.

p. $\quad \mathrm{cm}$.

Includes bibliographical references.

Contents: Introduction : narrative, sexuality, race, and the self - Querying postcolonial and borderland queer theory - John Rechy's bending of brown and white canons - Arturo Islas's and Richard Rodriguez's ethnosexual re-architexturing of metropolitan space - Ana Castillo's and Sheila Ortiz Taylor's bent Chicana textualities - Edward J. Olmos's postcolonial penalizings of the film-image repertoire - Conclusion : re-visioning Chicano/a bodies and texts.

ISBN 0-292-70689-8 (cloth : alk. paper) — ISBN 0-292-70940-4 (pbk. : alk. paper)

I. American literature-Mexican American authors-History and criticism. 2. Gays' writings, American-History and criticism. 3. Homosexuality and literature-United States. 4. Mexican American gays-Intellectual life. 5. Mexican Americans-Intellectual life. 6. Mexican Americans in literature. 7. Gender identity in literature. 8. Ethnicity in literature. 9. Sex role in literature. Io. Gays in literature. I. Title.

PSI53.M4A435 2005

810.9'353-dc22 